\title{
Understanding the Evolution and Socio-Economic Impacts of the Extreme Rainfall Events in March-May 2017 to 2020 in East Africa
}

\author{
Ladislaus Benedict Chang'a1, Agnes Lawrence Kijazi', Kantamla Biseke Mafuru', \\ Patricia Achieng Nying'uro ${ }^{2}$, Musa Ssemujju ${ }^{3}$, Bamanya Deus ${ }^{3}$, Alfred Lawrence Kondowe', \\ Isack Baliyendeza Yonah1, Mohamed Ngwali1, Sudi Yasini Kisama1, Gahigi Aimable4, \\ Joseph Ndakize Sebaziga ${ }^{4}$, Blandine Mukamana ${ }^{4}$
}

\footnotetext{
${ }^{1}$ Tanzania Meteorological Authority, Dar es Salaam, Tanzania

${ }^{2}$ Kenya Meteorological Department, Nairobi, Kenya

${ }^{3}$ Uganda National Meteorological Authority, Kampala, Uganda

${ }^{4}$ Rwanda Meteorology Agency, Kigali, Rwanda

Email: changa60@hotmail.com
}

How to cite this paper: Chang'a, L.B., Kijazi, A.L., Mafuru, K.B., Nying'uro, P.A., Ssemujju, M., Deus, B., Kondowe, A.L., Yonah, I.B., Ngwali, M., Kisama, S.Y., Aimable, G., Sebaziga, J.N. and Mukamana, B. (2020) Understanding the Evolution and Socio-Economic Impacts of the Extreme Rainfall Events in March-May 2017 to 2020 in East Africa. Atmospheric and Climate Sciences, 10, 553-572.

https://doi.org/10.4236/acs.2020.104029

Received: August 30, 2020

Accepted: October 12, 2020

Published: October 15, 2020

Copyright $\odot 2020$ by author(s) and Scientific Research Publishing Inc. This work is licensed under the Creative Commons Attribution International License (CC BY 4.0).

http://creativecommons.org/licenses/by/4.0/

(c) (i) Open Access

\begin{abstract}
This study aimed at assessing the evolution, distribution and the socio-economic impacts of extreme rainfall over East Africa during the March, April and May (MAM) rainfall season focusing on assessing the trends and contribution of MAM rainfall in mean annual rainfall across the region. It employed Principal Component Analysis (PCA) methods to capture the patterns and variability of MAM rainfall. The PCA results indicated that the first Principal Component (PC) describe $17 \%$ of the total variance, while the first six PCs account only $53.5 \%$ of the total variance in MAM rainfall, underscoring the complexity of rainfall forcing factors in the region. It has been observed that MAM rainfall accounts about $30 \%-60 \%$ of the mean annual rainfall in most parts of the region, signifying its importance in agriculture, water, energy and other socio-economic sectors. MAM has been characterized by increasing variability with varying trend patterns across the region. The MAM rainfall trend is not homogeneous across the region; some areas are experiencing a slight decreasing rainfall trend, while other areas are experiencing a slight increasing rainfall trend. The observed trend dynamics is consistent with the global trend patterns in precipitation as depicted in recent Intergovernmental Panel on Climate Change (IPCC) reports. Over the last five years MAM rainfall season have been characterized by record-breaking extremes. On $8^{\text {th }}$ May 2017, Tanga and Mombasa meteorological stations recorded $316 \mathrm{~mm}$ and
\end{abstract}


$235.1 \mathrm{~mm}$ of rainfall in 24 hours respectively, which are the highest amounts for these respective stations, since their establishment. Record highest 24 hours rainfall amounting to $134.9 \mathrm{~mm}$ and $119.4 \mathrm{~mm}$ were also observed at Buginyanya and Kawanda meteorological stations in Uganda on $18^{\text {th }}$ March 2018 and $7^{\text {th }}$ May 2020. On $6^{\text {th }}$ May 2020, Byimana meteorological station in Rwanda, also observed $140.6 \mathrm{~mm}$ of rainfall in 24 hours, the highest since its establishment. These extremes have caused multiple losses of life and property, and severe damages to infrastructure. Unfortunately, the frequency and intensity of these extremes are projected to increase under a changing regional climate patterns. It is therefore important that more studies are carried out to enhance understanding about the evolution, dynamics and predictability of these extremes in East Africa region.

\section{Keywords}

Extreme Rainfall Events, Principal Components, MAM, ENSO, IOD

\section{Introduction}

Socio-economic development and livelihood activities in most of the developing countries including East African countries are strongly affected by climate variability and change [1] [2] [3] [4] [5]. In most of the East African countries, the production and productivity in agriculture and livestock sectors are largely influenced by the availability and variability of rainfall amount of a particular season. Hydro-electricity that contributes about $30 \%$ of the total electricity consumption in Tanzania, is also strongly affected by rainfall variability associated with the extremes weather and climate events. The increase in climate variability and change is strongly manifested through the increase in frequency and intensity of extreme weather and climate events. Recent reports and records from climatological data from different parts of the world are overwhelmingly indicating an increase in the frequency and intensity of heavy precipitation and other extreme events including floods and droughts [1]-[7]. These extremes are projected to increase further at projected global warming of $1.5^{\circ} \mathrm{C}$ [1]. Heavy precipitation is projected to be more intense under a global warming of $2^{\circ} \mathrm{C}$ as compared to a warming of $1.5^{\circ} \mathrm{C}$ [1] [2] [3]. Warming levels reached $1.1^{\circ} \mathrm{C}$ in 2019 [8], and with business as usual scenario, warming is projected to reach $1.5^{\circ} \mathrm{C}$ between 2030 and 2052 [1] leading to intense extremes, which will have devastating, widespread and cascading implications to the livelihoods and socio-economic development of majority of the people in the developing countries including in East Africa, consequently affecting the attainment of the development vision and the achievement of Sustainable Development Goals. Therefore, a thorough understanding of the rainfall patterns including the evolution and dynamics of the extreme rainfall events in MAM rainfall season is critical for facilitating effective planning and implementation of development activities in all 
socio-economic sectors in East Africa region.

MAM rainfall season is one of the main and important rainfall season across much of the East African region and has recently been characterized by frequent and intense extreme rainfall events causing severe and devastating socio-economic and ecological impacts. The most recent extreme MAM rainfall was observed in 2017, 2018, 2019 and 2020 that caused death, destruction of houses and properties, and severe infrastructural damages in the region.

This study therefore aimed at assessing the spatial and temporal distribution of MAM rainfall for the purposes of depicting its current characteristics and trends and also depicting the evolution and assessing the impacts of extreme rainfall events in MAM 2017, 2018, 2019 and 2020. The study also aimed at establishing and understanding in the context of a changing climate, the main forcing factors responsible for the evolution of the extremes in the region.

\section{Data and Methodology}

\subsection{Description of the Study Area}

The East Africa (EA) region comprises of six countries namely; Tanzania, Kenya, Uganda, Burundi, Rwanda and South Sudan. However, the focus of this study is on Tanzania, Kenya, Uganda and Rwanda, located within the $5^{\circ} \mathrm{N}$ and $12^{\circ} \mathrm{S}$ and $29^{\circ} \mathrm{E}$ and $42^{\circ} \mathrm{E}$ (Figure 1 ). The region is characterized by diverse climate patterns due to complex topographical features. Rainfall is one of the climate parameters that is typified by stronger spatial and temporal variations, which is also amplified by significant differences in relief and vegetation cover. The large areas within the region receive bimodal rainfall pattern with "long rains" season in MAM and the "short rains" season in October, November and December (OND) respectively associated with the North-South-North seasonal movement of Inter Tropical Convergence Zone (ITCZ) as the main rain belt [9] (Nicholson, 2017) in East Africa. The ITCZ usually migrates southwards through Tanzania during OND, reaching the Southern parts of Tanzania and returning northwards during MAM. In Uganda and Rwanda, the "short rains" season starts a month earlier; running from September to October while some areas around the Lake Victoria basin and eastern regions of the Rift Valley experience tri-modal rainfall regime that peaks in June to July.

Variability of MAM and OND seasonal rainfall in East Africa is influenced by multiple factors including El Nino Southern Oscillation (ENSO) and Tropical Indian Ocean Dipole Mode (IOD) events manifested in the western Indian Ocean [9]-[16]. ENSO and IOD have significant impact on climate variability in East Africa in different time scale [16] [17] [18] [19].

\subsection{Data Sources and Type}

Daily and monthly rainfall data for the period 1961-2020 from selected synoptic stations in Tanzania, Kenya, Uganda and Rwanda were used in this study (Figure

1). The rainfall data were obtained from Tanzania Meteorological Authority 


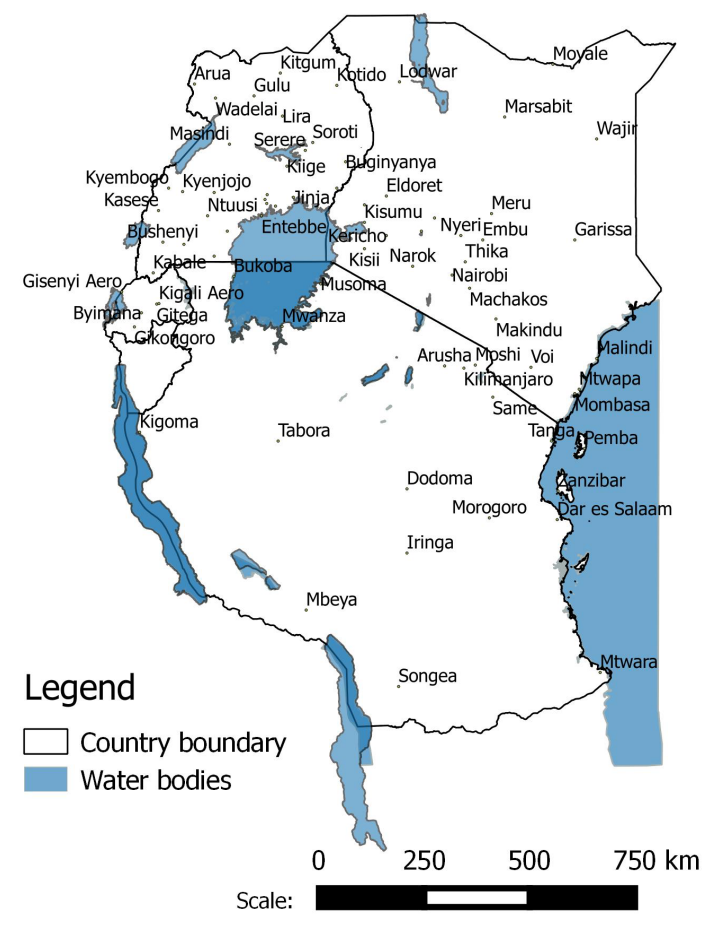

Figure 1. The stations used in the study.

(TMA), Kenya Meteorological Department (KMD), Uganda National Meteorological Authority (UNMA) and Rwanda Meteorology Agency (Meteo Rwanda). The study also made use of two gridded datasets; Global Precipitation Climatology Center (GPCC) and Infrared Precipitation with station data produced by Climate Hazards Group (CHIRPS). The CHIRPS [20] and GPCC data set are at $0.5^{\circ} \times 0.5^{\circ}$ grid spacing and are available at

https://data.chc.ucsb.edu/products/CHIRPS-2.0/global_daily/netcdf/p05/by_mo nth/ and https://www.esrl.noaa.gov/psd respectively. CHIRPS daily gridded data set is available from 1981 to near present. Data was accumulated into monthly totals (i.e., March, April and May) and seasonal totals (i.e., MAM). Furthermore, climatological rainfall accumulation for 1981-2010 was computed for the MAM season.

The study also made use of the monthly Sea Surface Temperature (SST) data sets from the National Oceanic and Atmospheric Administration (NOAA) with $2^{\circ} \times 2^{\circ}$ grid resolution for a period extending from 1960-2019 [21] to study the influence of IOD and ENSO on enhanced rainfall during MAM 2017, 2018, 2019 and 2020 .

\subsection{Methodology}

This study made use of simple statistical tools to compute and characterize the percentage contribution of MAM rainfall into mean annual rainfall, and employed the Empirical Orthogonal Function (EOF) to [21] characterize the variability of MAM and to analyze the large-scale inter-annual variability between the mean monthly rainfall over the EA and the mean Sea Surface Temperature Anomalies (SSTA) over the western Indian and Tropical Pacific Oceans during 
MAM rainfall season with particular interest in MAM 2017, 2018, 2019 and 2020 rainfall season. EOF analysis is frequently applied to derive patterns and indices used to identify climate modes as expressed in state variables [22]. The approach identifies patterns in space known as EOF modes in one or multiple variables from eigenvectors of the covariance matrix for the gridded data sets. Then the original centered data are projected onto the spatial patterns to obtain time series indices (i.e., the principal components, PCs). In this study, the first EOF spatial mode of the mean MAM rainfall over the EA is taken as the dominant mode and further explains areas that were associated with enhanced/suppressed mean MAM rainfall based on the 1981 to 2010 climatology. Subsequently, ascertaining the circulation anomalies responsible for the enhanced/suppressed mean MAM rainfall over the Eastern Africa based on 1981 to 2010. Composite analysis is carried out on a number of field variables and later test for their significance with the two tailed Student's t-test. The results for the composite analysis obtained hereafter are then compared with the anomalies for the years 2017, 2018, 2019 and 2020 to reveal the likely cause of the enhanced mean MAM rainfall in these years. In this case, the composite for the enhanced mean MAM rainfall is computed when the amplitude of the first principal component (PC1) is greater than or equal to +1 (i.e., years 1981, 1985, 1989 and 2006). Meanwhile, during suppressed mean MAM rainfall over the region the amplitudes are taken to be less than or equal to -1 (i.e., years 1983, 1984, 2000 and 2007). Quantifying the likely association between the enhanced/suppressed mean MAM rainfall with ENSO and IOD indices, the present study measures their association by correlating the mean MAM rainfall anomalies (i.e., PC1) with ENSO and IOD indices, and later assesses the strength of their association. In this case, the ENSO indices are computed by averaging the normalized SST over the Nino 3.4 domain while the IOD indices are expressed in terms of Dipole Mode Index (DMI), which defines the difference in SSTA between the western equatorial Indian Ocean and the south-eastern equatorial Indian Ocean [17]. The nonparametric test, Mann-Kendall trend [23] [24], was also used to detect the trend in time series for the mean MAM rainfall over the region and tested for the corresponding significance at $95 \%$ confidence interval. All anomalies were calculated with respect to 1981-2010 climatology.

\section{Results and Discussion}

\subsection{Contribution of MAM Rainfall to the Mean Annual Rainfall}

Characterization and quantification of the percentage contribution of the MAM rainfall in the mean annual rainfall is very important for climate monitoring and research related to climate variability and change. It provides a good benchmark for detecting shift in seasonal rainfall patterns. The percentage contribution of mean MAM rainfall in mean annual rainfall for the East African region is provided in Figure 2. For most parts of the region, MAM rainfall contributes between $30 \%$ and $50 \%$ of the mean annual rainfall underscoring its significant role in rain-fed agricultural activities and in water sectors. The distribution of MAM 


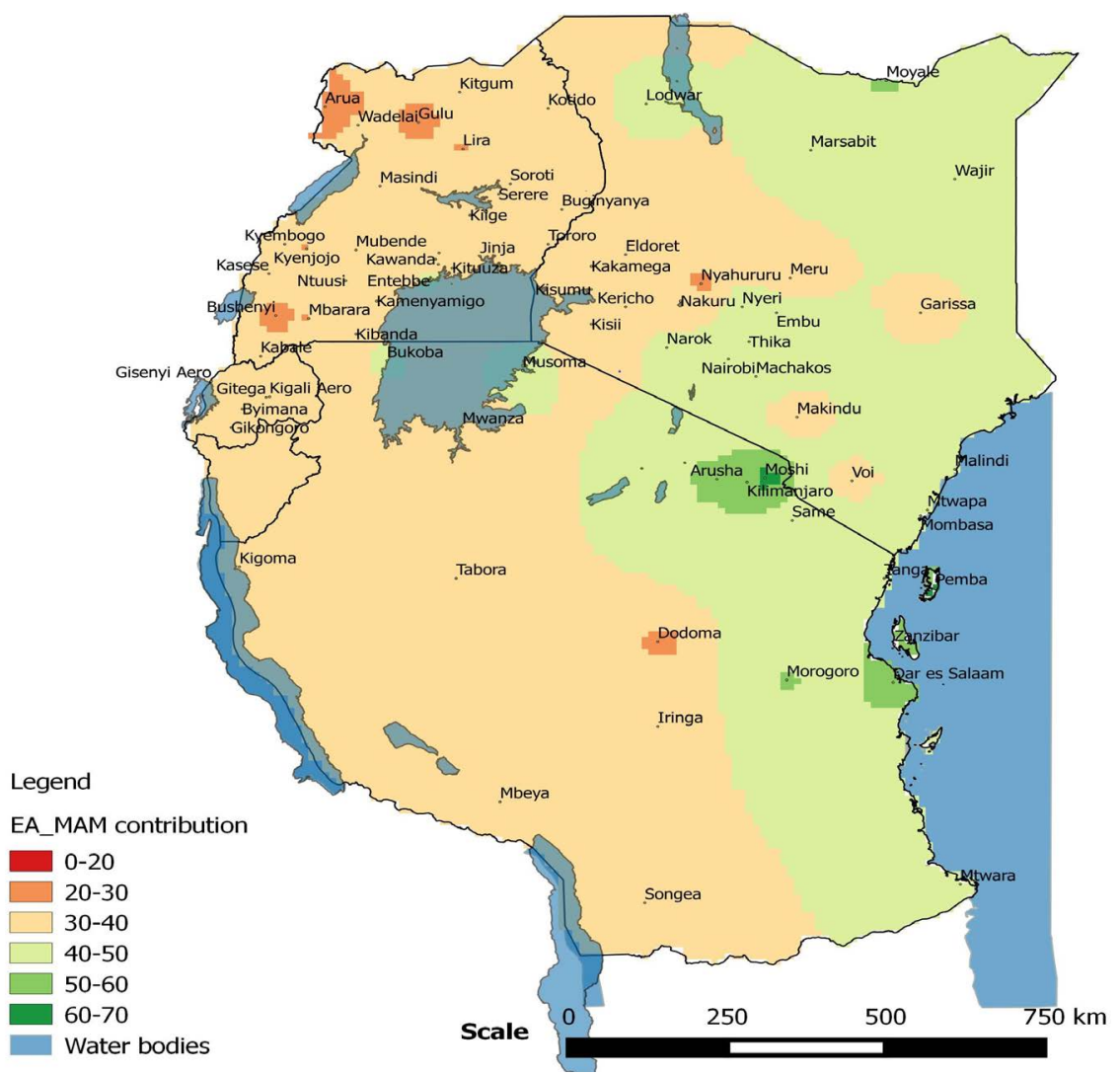

Figure 2. Percentage contribution of mean MAM rainfall to the Mean Annual rainfall.

rainfall in East Africa exhibit a well defined bipolar orientation with areas over the eastern side of the region and along the coast areas featuring between $40 \%$ and $50 \%$ of the annual rainfall, while areas over western side of the region featuring between $30 \%$ and $40 \%$ slightly lower contribution as compared to the eastern side of the region. The higher percentage contribution over the eastern side of the region could be amplified by moisture influx from of Indian Ocean and the dynamics of the Indian Ocean Dipole (IOD). In few areas in Tanzania, including areas around Dar es Salaam, Kilimanjaro, Moshi and Arusha, MAM contribution in the mean annual rainfall is more pronounced; it ranges between $50 \%$ to $60 \%$. The remaining seasons combined, including the October-December (OND), January-February (JF) and June, July, August and September (JJAS) add up to the remaining $40 \%$ to $50 \%$.

\subsection{Recent Trend of March, April and May Rainfall Season}

Over the recent decades, most parts of East Africa have experienced an increase in frequency and intensity of heavy precipitation events, which have caused severe infrastructural damages and devastating socio-economic impacts. The March-May (MAM) rainfall season over the last four years (2017, 2018, 2019 and 2020) have been characterized by record-breaking extreme rainfall events (Tables 1-4), which had significantly affected the dynamics of the rainfall patterns and the associated trend. The observed MAM rainfall trend is not homo- 
geneous across the region, though most of the stations exhibited a slight increasing rainfall trend (Figures 3-6). Trend analysis for MAM rainfall for Nyamagabe, Nyagatare and Rubavu meteorological stations in Rwanda depicts a slight increasing rainfall trend (Figure 3). Increasing trend in MAM rainfall is also depicted in Lodwar, Nyahururu, and Kakamega meteorological stations in Kenya (Figure 4), Entebbe meteorological station in Uganda (Figure 6) and Zanzibar meteorological station in Tanzania (Figure 5), while slight decreasing MAM rainfall trend is observed in Narok Meteorological station in Kenya, and Mbeya, Dodoma and Arusha meteorological stations in Tanzania, and Kigali, Kamembe and Musanze meteorological stations in Rwanda. These results indicate a complexity inherent in the MAM rainfall patterns and dynamics in the region, the stronger spatial and temporal variability, which is largely amplified by complex topographical features and multiple forcing factors associated with rainfall regime in the region.

Table 1. Highest 24 hours extreme rainfall events and their associated impacts during MAM 2017, 2018, 2019 and 2020 rainfall season in Tanzania.

\begin{tabular}{|c|c|c|c|c|}
\hline Event date & $\begin{array}{l}\text { Station Name and } \\
\text { Establishment year } \\
\text { and location }\end{array}$ & $\begin{array}{l}24 \text { hours rainfall } \\
(\mathrm{mm})\end{array}$ & $\begin{array}{l}\text { Rank of } \\
\text { the event }\end{array}$ & Impacts \\
\hline 8 May 2017 & $\begin{array}{l}\text { Tanga } \\
\text { Latitude: } 5^{\circ} 5^{\prime} \\
\text { Longitude: } 39^{\circ} 4^{\prime} \\
\text { Elev: } 49 \mathrm{~m}\end{array}$ & 316.0 & $1^{\mathrm{s}}$ & $\begin{array}{l}7 \text { deaths, } 5 \text { injuries, } 100 \text { people left homeless, } \\
\text { flooded Mkumbara river and rocks fall destruct } \\
\text { roads. (Habari Leo, } 10^{\text {th }} \text { May 2017; Mtanzania } \\
\text { Newspaper, } 13^{\text {th }} \text { May 2017) }\end{array}$ \\
\hline 6 May 2019 & $\begin{array}{l}\text { Pemba } \\
\text { Lat: } 5.15 \\
\text { Lon: } 39.49 \\
\text { Elev: } 24 \mathrm{~m}\end{array}$ & 181 & $7^{\text {th }}$ & $\begin{array}{l}\text { Flooding, houses destroyed, } \\
\text { infrastructure including road and bridge damaged }\end{array}$ \\
\hline 15 April 2018 & $\begin{array}{l}\text { Dar es Salaam } \\
\text { Lat: } 6.52 \\
\text { Lon: } 39.12 \\
\text { Elev: } 53 \mathrm{~m}\end{array}$ & 91.3 & $8^{\text {th }}$ & $\begin{array}{l}14 \text { deaths, } 9 \text { houses destroyed, over } 600 \text { families } \\
\text { left homeless and transport lines were shut down } \\
\text { due to flooded infrastructure. } \\
\text { Dar es Salaam Zonal Police office, } 16^{\text {th }} \text { April } 2018\end{array}$ \\
\hline 17 April 2020 & $\begin{array}{l}\text { Zanzibar } \\
\text { Lat: } 6^{\circ} 13^{\prime} \\
\text { Lon: } 39^{\circ} 13^{\prime} \\
\text { Elev: } 18 \mathrm{~m}\end{array}$ & 202.6 & 6 & $\begin{array}{l}\text { Flooding, Destruction of } \\
\text { Settlements and infrastructure }\end{array}$ \\
\hline 27 March 2017 & $\begin{array}{l}\text { Ilonga } \\
\text { Lat: } 6.46 \\
\text { Lon: } 37.2 \\
\text { Elev: } 502 \mathrm{~m}\end{array}$ & 105.4 & $5^{\text {th }}$ & $\begin{array}{l}\text { Settlements destructed and } \\
\text { hectors of farm field destructed }\end{array}$ \\
\hline 28 April 2018 & $\begin{array}{l}\text { Arusha } \\
\text { Lat: } 3^{\circ} 22^{\prime} \\
\text { Lon: } 36^{\circ} 38^{\prime} \\
\text { Elev: } 1372 \mathrm{~m}\end{array}$ & 126.4 & 4 & $\begin{array}{l}2 \text { deaths, Roads flooded and transportation } \\
\text { difficulties }\end{array}$ \\
\hline 18 April 2018 & $\begin{array}{l}\text { Kilimanjaro } \\
\text { Lat: } 3.25 \\
\text { Lon: } 37.4 \\
\text { Elev: } 891 \mathrm{~m}\end{array}$ & 85.2 & $7^{\text {th }}$ & $\begin{array}{l}\text { Severe Infrastructure damage, } \\
477 \text { crop field destroyed }\end{array}$ \\
\hline
\end{tabular}


Table 2. Highest 24 hours extreme rainfall events and their associated impacts during MAM 2017, 2018, 2019 and 2020 rainfall season in Kenya.

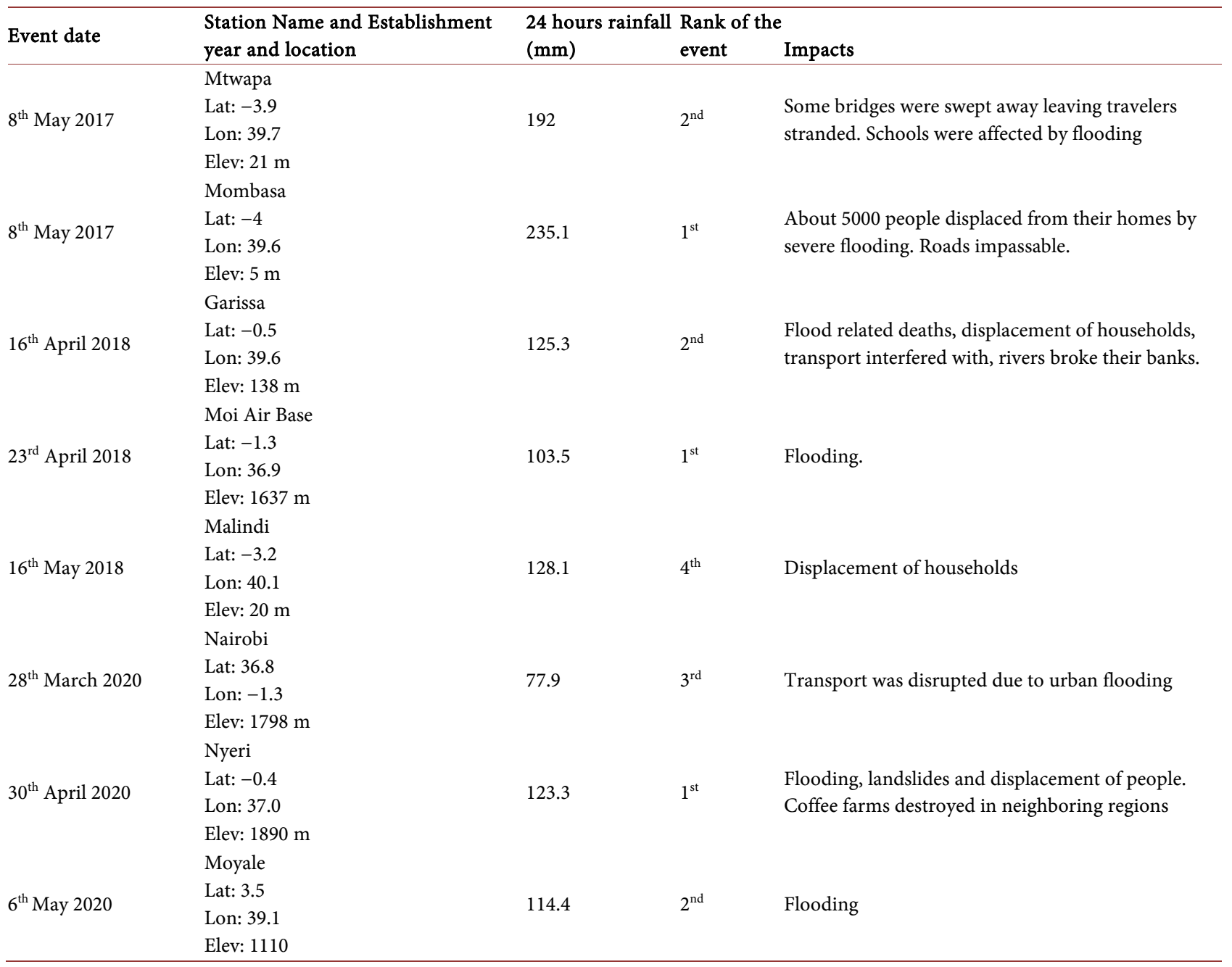

Table 3. Highest 24 hours extreme rainfall events and their associated impacts during MAM 2017, 2018, 2019 and 2020 rainfall season in Uganda.

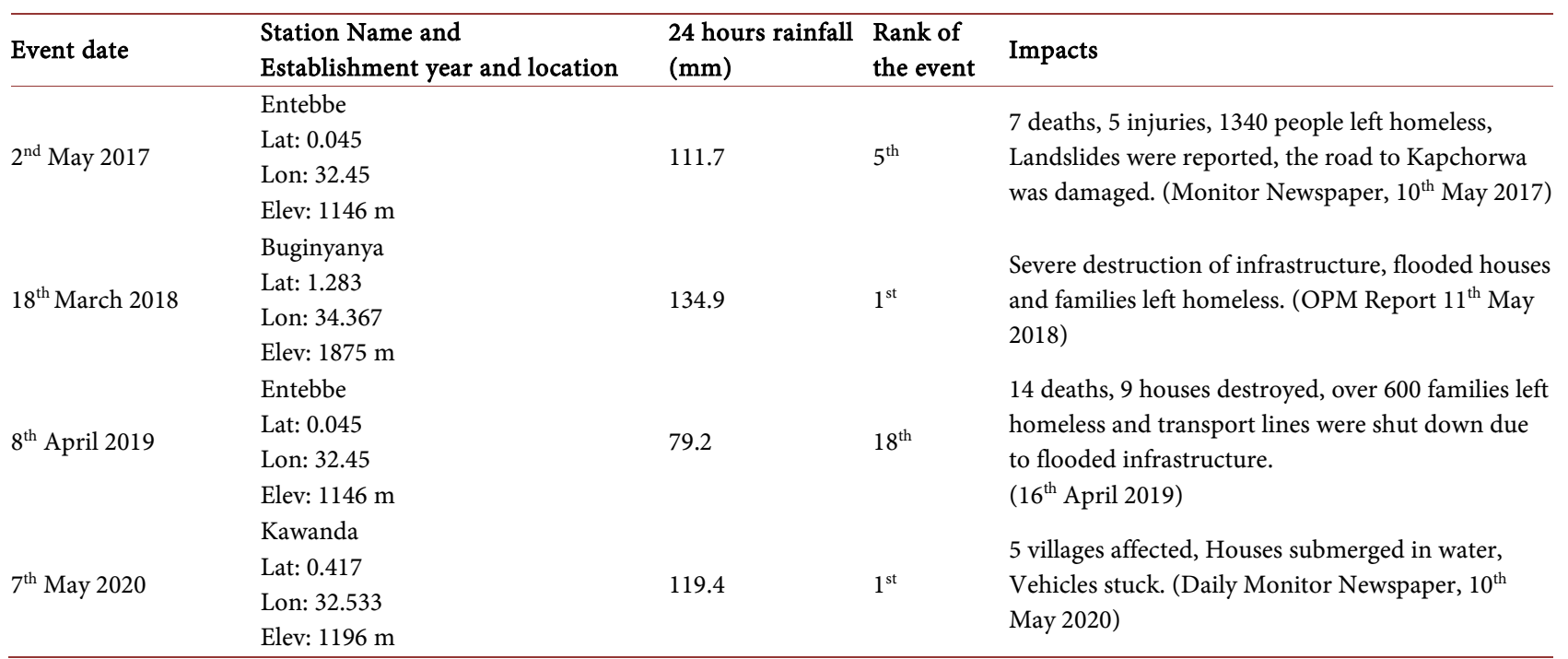


Table 4. Highest 24 hours extreme rainfall events and their associated impacts during MAM 2017, 2018, 2019 and 2020 rainfall season in Rwanda.

\begin{tabular}{|c|c|c|c|c|}
\hline Event date & $\begin{array}{l}\text { Station Name and Establishment } \\
\text { year and location }\end{array}$ & $\begin{array}{l}24 \text { hours rainfall } \\
(\mathrm{mm})\end{array}$ & $\begin{array}{l}\text { Rank of } \\
\text { the event }\end{array}$ & Impacts \\
\hline \multirow{4}{*}{$16 / 04 / 2020$} & Gitega & \multirow{4}{*}{96} & \multirow{4}{*}{1 st } & \\
\hline & Lat: -1.96 & & & Floods resulted in 1 Death, 1 injured, \\
\hline & Lon $=30.06$ & & & 3 Roads and 3 Houses damaged \\
\hline & Elev $=1474 \mathrm{~m}$ & & & \\
\hline \multirow{3}{*}{$05 / 03 / 2020$} & Nyagatare & \multirow{3}{*}{82.4} & \multirow{3}{*}{$1^{\text {st }}$} & \multirow{3}{*}{ Flooding in some area } \\
\hline & Lon: 30.31 & & & \\
\hline & Elev: $1377 \mathrm{~m}$ & & & \\
\hline \multirow{3}{*}{$27 / 04 / 2018$} & Rubengera Met & \multirow{3}{*}{89.4} & \multirow{3}{*}{$1^{\text {st }}$} & \multirow{3}{*}{ Flood caused destruction of bridge } \\
\hline & $\begin{array}{l}\text { Lat: }-2.05 \\
\text { Lon: } 29.41\end{array}$ & & & \\
\hline & Elev: $1700 \mathrm{~m}$ & & & \\
\hline \multirow{3}{*}{$01 / 03 / 2020$} & Kigali aero & \multirow{3}{*}{71} & \multirow{3}{*}{$1^{\text {st }}$} & \multirow{3}{*}{$\begin{array}{l}\text { Heavy rain caused } 1 \text { injured, } \\
\text { and } 8 \text { Houses damaged }\end{array}$} \\
\hline & Lon $=30.11$ & & & \\
\hline & Elev $=1490 \mathrm{~m}$ & & & \\
\hline $06 / 05 / 2020$ & $\begin{array}{l}\text { Byimana } \\
\text { Lat: }-2.16 \\
\text { Lon }=29.71 \\
\text { Elev }=1750 \mathrm{~m}\end{array}$ & 140.6 & $1^{\text {st }}$ & $\begin{array}{l}\text { Rainstorm caused } 1 \text { death, } 2 \text { injuries, } 13 \text { houses } \\
\text { destroyed, } 2 \text { Lost Cattles, destroyed } 1 \text { road, and } 1 \\
\text { transmission line }\end{array}$ \\
\hline \multirow{4}{*}{$21 / 04 / 2020$} & Byimana & \multirow{4}{*}{79.3} & \multirow{4}{*}{$3^{\text {rd }}$} & \\
\hline & Lat: -2.16 & & & Rainstorms and Landslides caused 3 Deaths, 1 \\
\hline & Lon $=29.71$ & & & Road and 3 Houses damaged \\
\hline & Elev $=1750 \mathrm{~m}$ & & & \\
\hline \multirow{3}{*}{$01 / 04 / 2018$} & Byimana & \multirow{3}{*}{74.7} & \multirow{3}{*}{$6^{\text {th }}$} & \\
\hline & Lat: -2.16 & & & Rainstorms resulted in 20 Houses damages, 0.5 \\
\hline & Lon $=29.71$ & & & Damages in crops $\mathrm{Ha}$ \\
\hline \multirow{3}{*}{$18 / 04 / 2020$} & Lat: -1.6 & \multirow{3}{*}{69.7} & \multirow{3}{*}{$3^{\mathrm{rd}}$} & Landslides/resulted in 2 Houses damaged and 2 \\
\hline & Lon $=30.05$ & & & Roads and Rainstorms caused 15 Houses damaged \\
\hline & Elev $=2235 \mathrm{~m}$ & & & \\
\hline
\end{tabular}

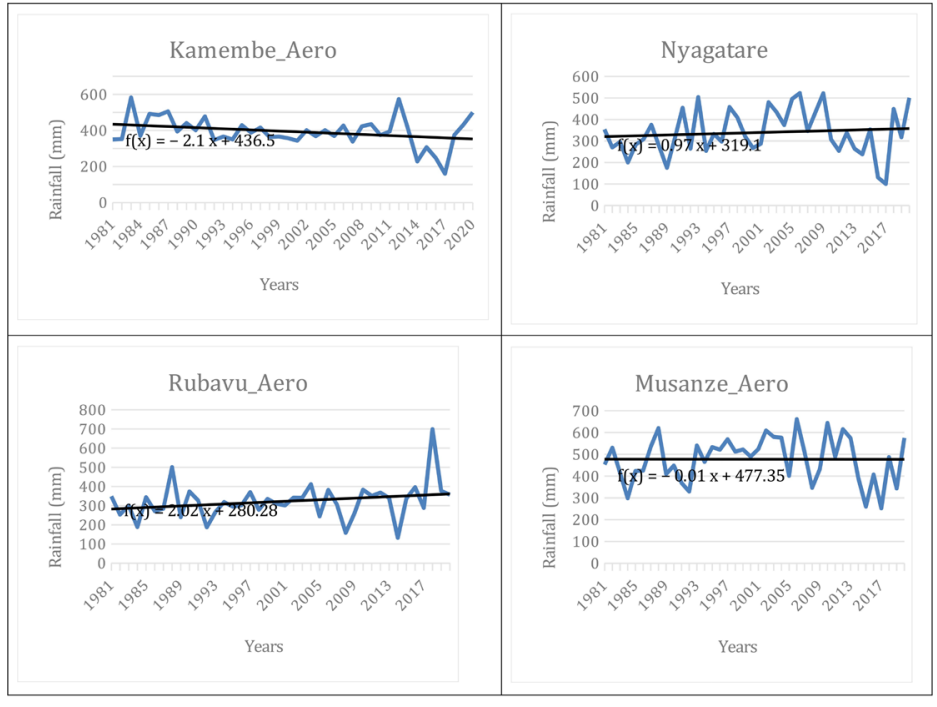

Figure 3. Trend in MAM rainfall for selected stations in Rwanda (Source: Rwanda Meteorology Agency). 


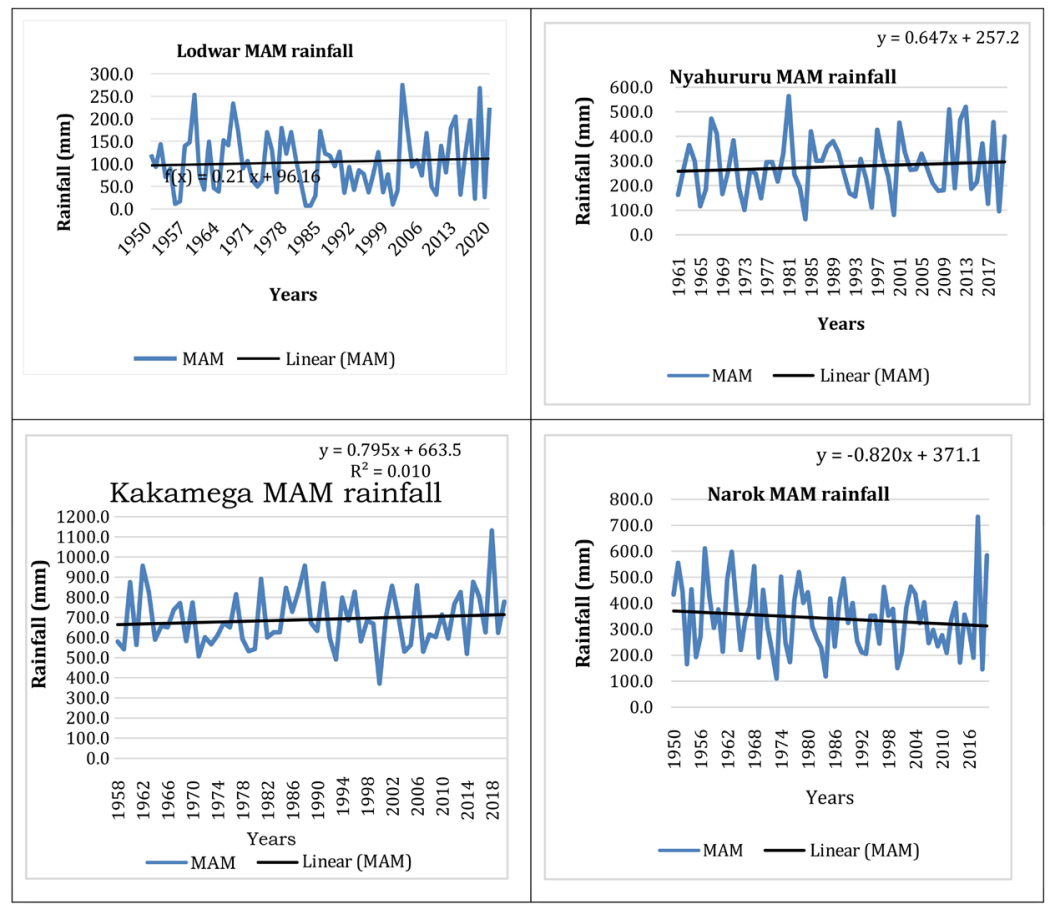

Figure 4. Trend in MAM rainfall for selected stations in Kenya (Source: Kenya Meteorological Department).

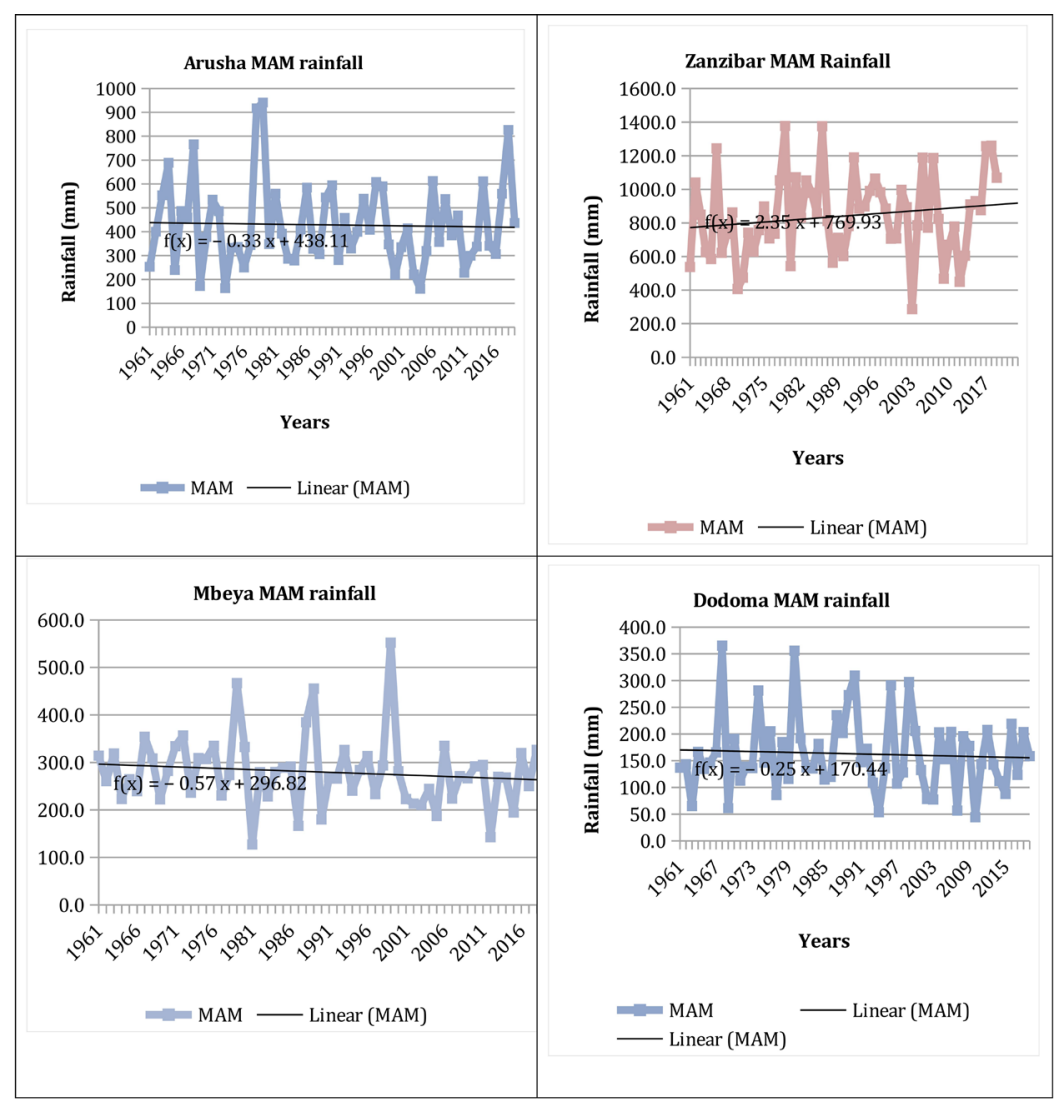

Figure 5. Trend in MAM rainfall for selected stations in Tanzania (Source: Tanzania Meteorological Authority). 


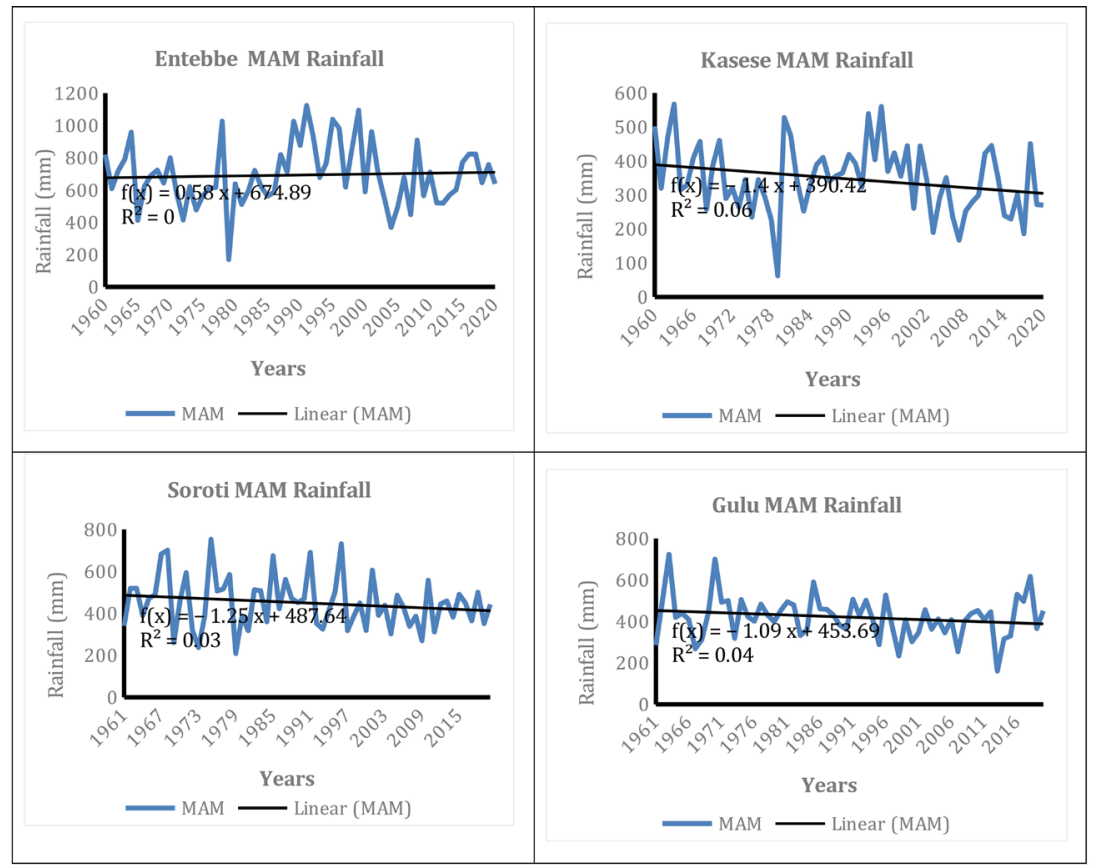

Figure 6. Trend in MAM rainfall for selected stations in Uganda (Source: Uganda National Meteorological Authority).

It can be noted that, the sequential MK trend test applied in this study graphically illustrates the forward, $u(F)$, and backward, $u(B)$, trends of heavy rainfall over few selected countries over the Eastern Africa (Tanzania, Uganda and Kenya) as indicated in Figure 7. When a set of two series, a forward and backward one, cross each other and diverge beyond the specific threshold value (i.e., $\alpha=0.05$ significant level for this study), the point is said to be a significant change point. [25] assumed that the point is the approximate year when the trend begins, while [26] referred to it as the period at which the critical point of change occurs. [27] noted that, extreme weather events (i.e., heavy rainfall events) reveals an alarming increasing in trend over most area in Tanzania. However, the typical sequential MK trend test over Tanzania in Figure 7(a) shows that, even though extreme heavy rainfall events are in increasing trend [27] but generally the mean MAM rainfall indicates the decrease in trend at 95\% confidence interval. It reveals period of abrupt decline in trend from 1995 to 2019 which became significant at 0.05 confidence levels in 2020. Subsequently, the mean MAM rainfall over Kenya (Figure $7(\mathrm{c})$ ) indicates a decrease in trend though insignificant at $95 \%$ confidence interval. Generally, the large climatological window (1981 to 2012), revealed the decrease in trend of the mean MAM rainfall over Uganda (Figure $7(\mathrm{~b})$ ) and thereafter leaned towards increasing trend (i.e., from 2012) though insignificant at 95\% confidence interval.

\subsection{Evolution and Distribution of Rainfall in MAM 2017, 2018, 2019, and 2020 Rainfall Season in East Africa}

In recent years, the distribution of MAM rainfall in East Africa has been charac- 
terized by increasing variability on both spatial and temporal scales (Figure 8). In 2017, most parts of East Africa, with exceptional of some parts of southern areas, and areas along the coast of Tanzania were characterized by below normal MAM rainfall. In 2018 and 2020, most parts of the region experienced above normal rainfall (Figure 8 and Figure 9), which was likely associated with the positive phase of the Indian Ocean Dipole.

The increasing variability of MAM rainfall is also manifested in the observed late onset, long dry spells and record-breaking climate extremes, in the form of heavy precipitation. For the year 2017, MAM rainfall season was comparatively above normal in most parts of the East African region. Cumulatively, Tanga meteorological stations in Tanzania (Figures 10) experienced well above normal. However, it can be discerned that the above normal rainfall was largely contributed by the record-breaking extreme rainfall events that was observed on $8^{\text {th }}$ May 2017, whereby the Tanga station recorded $316 \mathrm{~mm}$ of rainfall in 24 hours, which is the highest ever recorded 24 hours rainfall since the establishment of the station in 1941. These results are consistent with observed and projected increase in the frequency and intensity of extreme heavy precipitation events [1] [2] [6].

(a) Tanzania

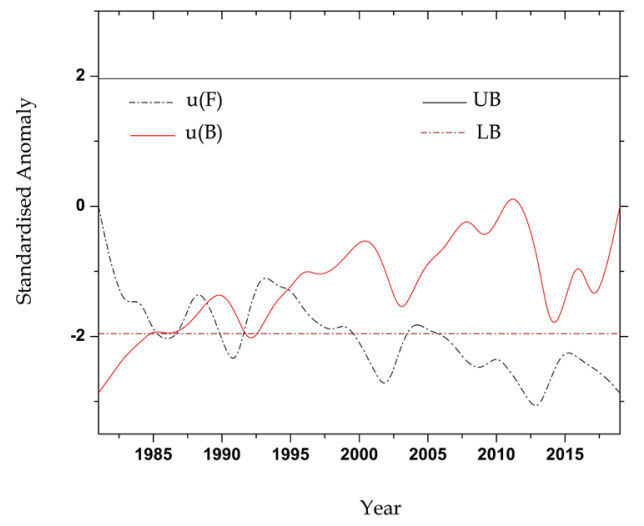

(b) Uganda

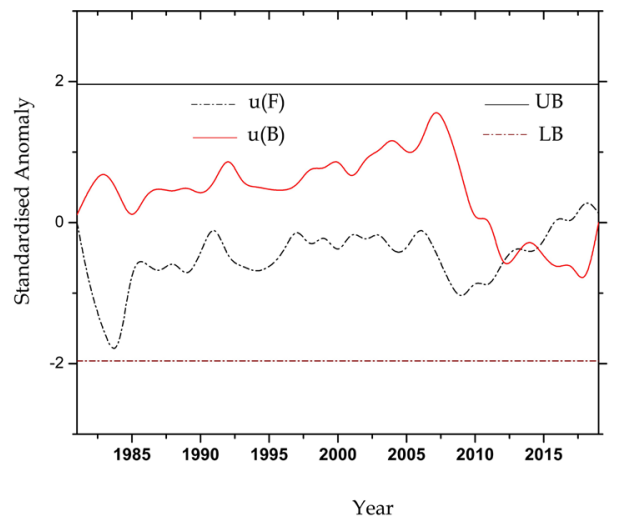

(c) Kenya

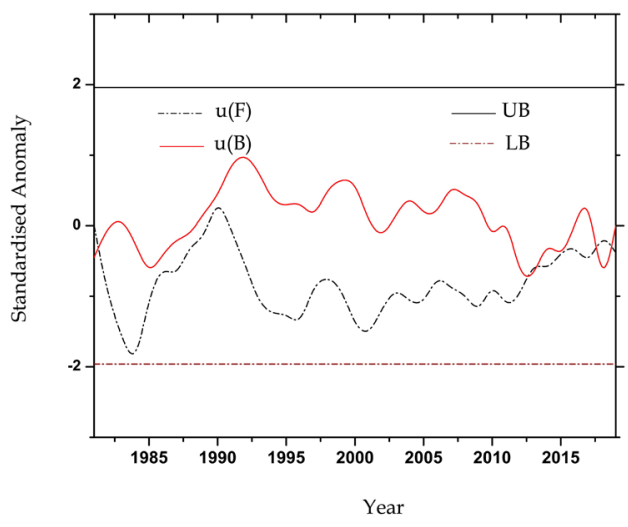

Figure 7. The sequential Mann-Kendall tests of the mean MAM rainfall over (a) Tanzania (b) Uganda and (c) Kenya. Dotted and solid horizontal lines indicate critical values corresponding to $95 \%$ confidence interval. 

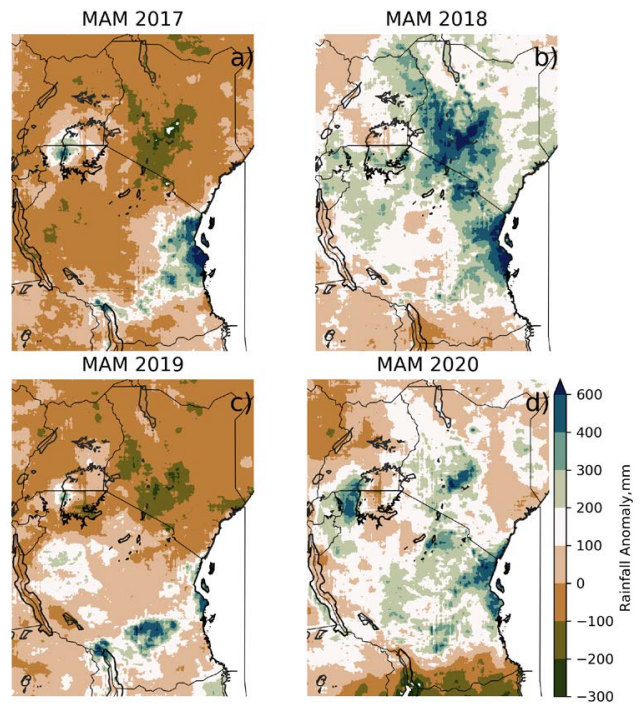

Figure 8. Spatial distribution of MAM rainfall for 2017, 2018, 2019 and 2020 over East Africa.
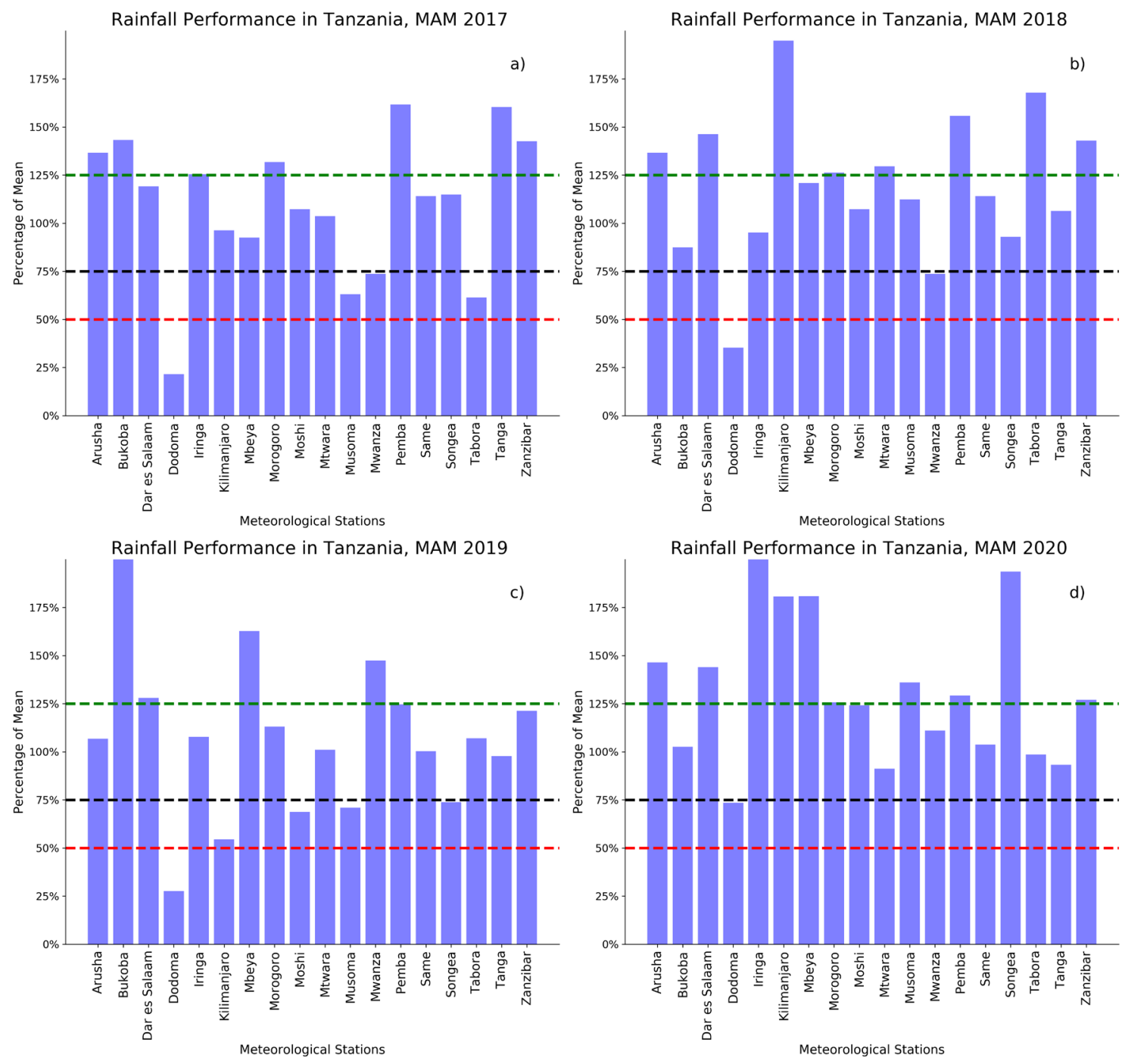

Figure 9. Performance of MAM rainfall for 2017, 2018, 2019 and 2020 in Tanzania. 

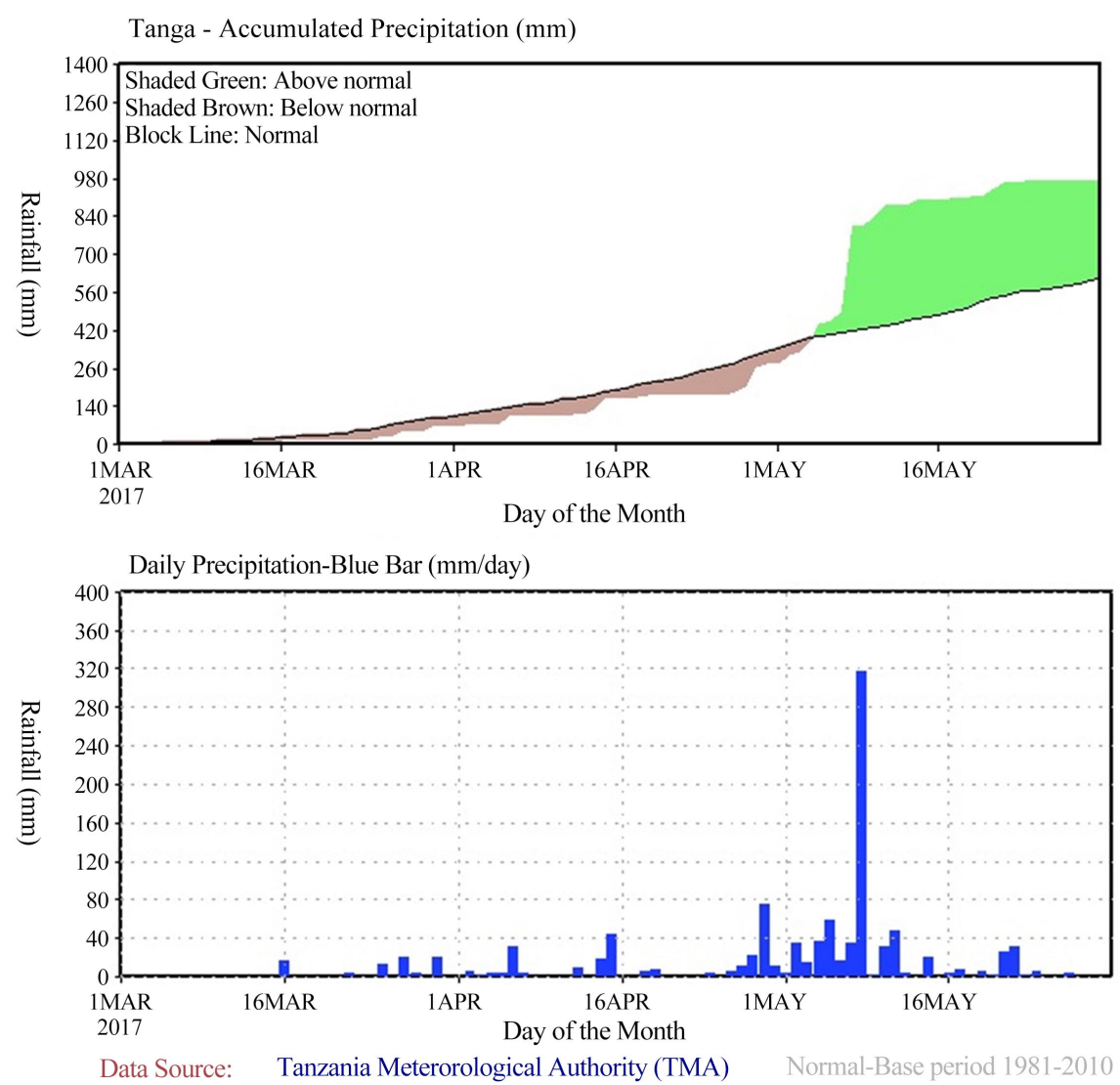

Figure 10. Intra-seasonal distribution of MAM 2017 rainfall for Tanga meteorological station in Tanzania.

\subsection{Principal Component Analysis of MAM Rainfall in East Africa}

Using CHIRPS dataset, the Principal Component Analysis (PCA) of the MAM rainfall in the region was performed to capture the patterns and variability of the MAM rainfall for the period 1981-2010. The PCA analysis indicates that the first Principal Components accounts only about $17 \%$ of the total MAM rainfall variance (Figure 11), while the first six Principal Components only accounts for $53.5 \%$ of the total MAM rainfall variance underscoring the complexity associated with rainfall patterns in the region. The second and third Principal Components are presented in Figure 12, and they account for $12.4 \%$ and $6.9 \%$ of the total variance respectively. It is evident that, unanimous positive loading anomalies (Figure 11(a)) are concentrated over the bimodal areas of Tanzania (northern sector), many areas of Rwanda and Burundi, the central to southern Kenya and the southern Uganda (along the Lake Victoria basin). Meanwhile, EOF2 and EOF3 (Figure 12) still reveal the same scenario with positive coefficients over the areas recaptured by EOF1. Notably, the results in Figure 11 and Figure 12 postulates the fact that the interannual variability of enhanced mean MAM rainfall over the region concentrates over the bimodal areas of Tanzania (northern sector), much areas of Rwanda and Burundi, the central to southern Kenya and the southern Uganda (along the Lake Victoria basin). 
(a) EOF1 $(17.04 \%)$

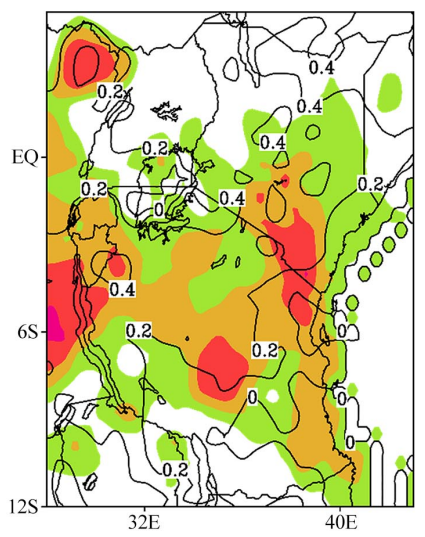

(b) $\mathrm{PC} 1$

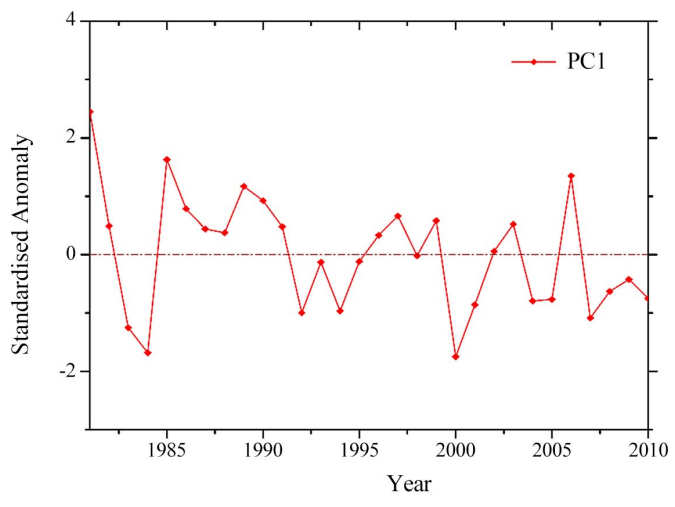

Figure 11. The first EOF mode (EOF1) of the mean MAM rainfall anomaly over the Eastern Africa in (a) and its corresponding time series coefficient (PC1) in (b) during MAM of 1980-2010. EOF1 explains 17\% of the total variance.

(a) EOF2 (12.41\%)

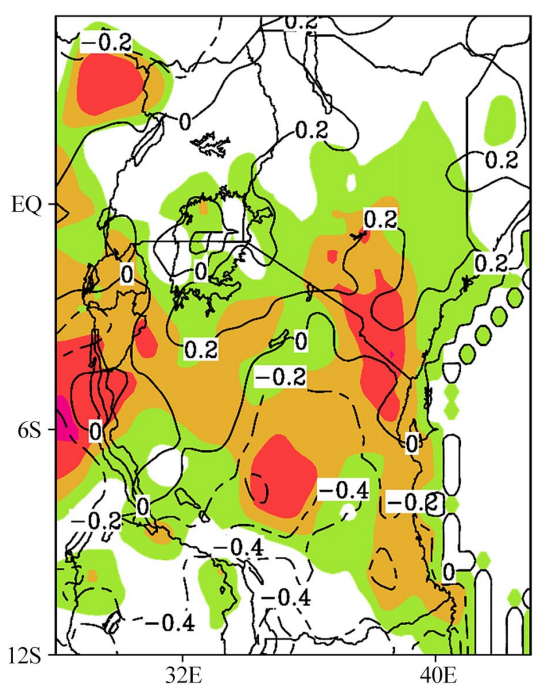

(b) EOF3 (6.92\%)

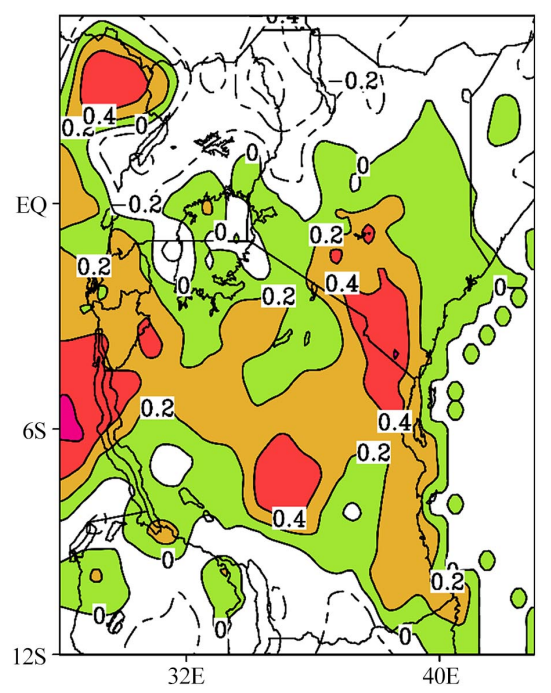

Figure 12. The second and third EOF modes of the mean MAM rainfall anomaly over the Eastern Africa in (a) and (b) respectively during MAM of 1980-2010. EOF2 and EOF3 explain $19 \%$ of the total variance.

\subsection{Circulation Anomalies Associated with Extreme Rainfall}

Based on the results obtained from the composite analysis by a number of field variables to ascertain the likely cause of enhanced mean MAM rainfall over the region, the study revealed the fact that; enhanced rainfall during MAM over the EA domain linked with enhanced convection following the positioning of the ascending limb of the Walker circulation over the eastern Africa. For instance, Figure 13 represents the composite velocity potential and divergent wind anomalies during enhanced mean MAM rainfall based on 1981 to 2010 climatology. At the low level (i.e., $850 \mathrm{hPa}$ ) in Figure 13(a) the center of positive velocity potential is associated with confluent inflow (convergence) of the winds. Meanwhile, the center of negative velocity potential in the upper troposphere (i.e., 200 
(a) $850 \mathrm{hPa}$ V. Potential, Wet Years

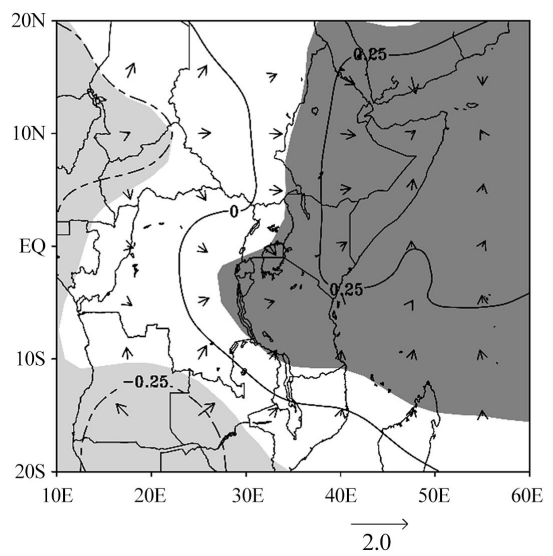

(b) $200 \mathrm{hPa}$ V. Potential, Wet Years

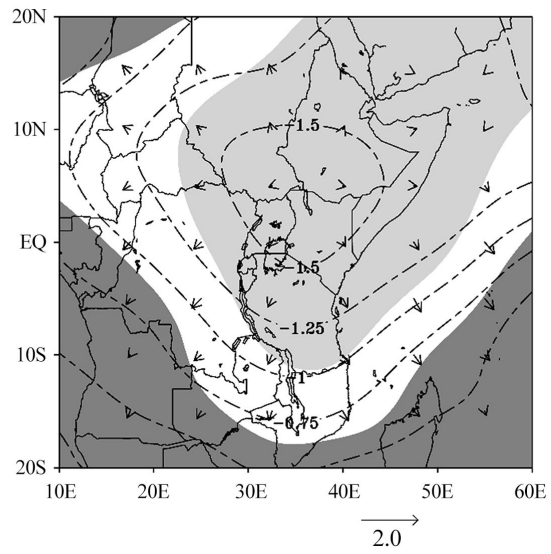

Figure 13. The composite pattern for the velocity potential $\left(106 \mathrm{~m}^{2} \cdot \mathrm{s}^{-1}\right)$ and divergent wind $\left(\mathrm{m} \cdot \mathrm{s}^{-1}\right)$ anomalies, at (a) $850 \mathrm{hPa}$ and (b) $200 \mathrm{hPa}$ during enhanced mean MAM rainfall season of 1981 to 2010 . Shaded areas are statistically significant at $5 \%$ level with a two tailed Student's t test.

$\mathrm{hPa}$ ) in Figure 13(b) is accompanied with outflow (divergence) of the winds. This condition reflects the anomaly positioning of the ascending limb of the local Walker circulation over the western Indian Ocean (WIO), which is likely responsible for the enhanced MAM rainfall. In their study in assessing prone areas to heavy rainfall and the impaction of the upper warm temperature anomaly (UWTA) in Tanzania, [27] also revealed the notable influence of the Walker circulation among other factors in enhancing rainfall anomalies during MAM.

Correspondingly, the composite analysis for the in phase SSTA during MAM season over both the Indian and Pacific Oceans (figures are not included in this study) for enhanced mean MAM rainfall are indicating slightly cooler SSTA over the larger domain of the Indian Ocean and over the central and tropical Pacific Ocean. The scenario suggests the fact that IOD and ENSO during the in-phase condition have less influence on extreme MAM rainfall over the region. However, studying the influence of ENSO on UWTA associated with heavy rainfall in Tanzania during MAM rainfall season, [27] noted that, enhanced SSTA over the central Pacific Ocean six (6) months lead time (i.e., warm phase of ENSO during the previous SON) has influence on enhanced rainfall the following MAM. Meanwhile, the in-phase correlation analysis between the mean MAM rainfall (PC1 in Figure 11(b)) over the EA with ENSO and IOD indices (figures are not included) revealed the weak positive correlation.

\subsection{Socio-Economic Impacts of Extreme Rainfall in 2017, 2018, 2019 and 2020 MAM Rainfall Season in East Africa}

Over the last ten years, an upsurge in the frequency and intensity of extreme events has been widespread and consequential (Tables 1-4). During the MAM rainfall season in 2017, 2018, 2019 and 2020, most parts of the region were affected by record-breaking extreme rainfall events of historical magnitude. On $8^{\text {th }}$ 
May 2017, for example, Tanga meteorological station in Tanzania recorded 316 $\mathrm{mm}$ of rainfall in 24 hours, while Mombasa meteorological station in Kenya recorded $235.1 \mathrm{~mm}$ on the same day. These were the highest ever-recorded 24 hours rainfall in both Tanga and Mombasa since their establishment in 1941 and 1946 respectively. On $8^{\text {th }}$ March 2018, Buginyanya Meteorological station in Uganda recorded $134.9 \mathrm{~mm}$ of rainfall, which is also the highest recorded 24 hours rainfall since its establishment in 1964. On $6^{\text {th }}$ May 2020, Byimana meteorological station in Rwanda recorded $140.6 \mathrm{~mm}$ of rainfall in 24 hours, which is the highest ever recorded 24 hours rainfall, since its establishment in 1959. These observed extreme rainfall events have been causing devastating socio-economic impacts in many parts of the regions, and their dynamics are consistent with global patterns of extreme events that are comprehensively characterized in recent IPCC report (IPCC, 2012, 2018) indicating observed and projected increase in the frequency and intensity of heavy precipitation in some parts of the world. Few examples of some cases of the extreme rainfall events during the MAM rainfall season in Tanzania, Kenya, Uganda and Rwanda are provided in Tables 1-4. Unfortunately, loss of life and properties, significant infrastructural damages including devastating destruction of houses, roads and crops farms have been increasingly associated with these weather and climate extremes (Tables 1-4). According to World Bank study [28], it was estimated that the household losses due to April 2018 flooding in Dar es Salaam reached more than US\$100 million, representing about 2 - 4 percent of the gross domestic product of Dar es Salaam. More details about impacts of floods in Dar es Salaam are described in [4].

\section{Conclusion and Recommendation}

On average MAM rainfall accounts about $30 \%$ to $60 \%$ of the mean annual rainfall in most parts of East Africa, underscoring the significant importance attached to MAM rainfall season in the region, particularly for agriculture, livestock, water and energy sectors. Over the recent years, MAM rainfall has been characterized by increasing spatial and temporal variability with varying trend patterns across the region. The MAM rainfall trend is not homogeneous; some areas are experiencing slight decreasing rainfall trend, while other areas are experiencing a slight increasing rainfall trend. The observed differentiated trend dynamics are consistent with the global trend patterns in precipitation as depicted in recent IPCC reports.

The increasing variability of MAM rainfall is further aggravated by the incidences of extreme weather and climate events, particularly heavy precipitation, which have been observed to increase in both frequency and intensity, and are becoming widespread and increasingly consequential across the East African region. Recording breaking heavy precipitation events have been observed in many meteorological stations across the region over the last five years. On $8^{\text {th }}$ May 2017, Tanga meteorological station in Tanzania and Mombasa meteorological station in Kenya recorded $316 \mathrm{~mm}$ and $235.1 \mathrm{~mm}$ of rainfall in 24 hours, 
which are the highest ever recorded 24 hours rainfall since the establishment of those stations. On $18^{\text {th }}$ March 2018 and $7^{\text {th }}$ May 2020, Buginyanya and Kawanda meteorological stations in Uganda observed $134.9 \mathrm{~mm}$ and $119.4 \mathrm{~mm}$ of rainfall in 24 hours, which are the highest ever recorded 24 hours rainfall since the establishment of these two stations in 1964 and 1938 respectively.

On $6^{\text {th }}$ May 2020, Byimana meteorological station in Rwanda, observed 140.6 $\mathrm{mm}$ of rainfall in 24 hours, which is the highest ever recorded rainfall since its establishment in 1959.

These extreme events have been and are increasingly attributed for significant flooding, loss of life and properties, and severe infrastructure damages including destruction of roads, houses and crops farm across the region and severely hampering poverty eradication efforts and attainment of Sustainable Development Goals. Understanding the dynamics of the forcing factors responsible for modulating the extreme events in the context of climate change for enhanced early warning of these extreme is highly recommended.

\section{Acknowledgements}

The authors wish to thank The Tanzania Meteorological Authority, Kenya Meteorological Department, Uganda National Meteorological Authority, and Rwanda Meteorology Agency for the provision of meteorological data. We sincerely thank National Oceanic and Atmospheric Administration (NOAA), Global Precipitation Climatology Center (GPCC) and climate hazards group infrared precipitation with station data (CHIRPS) for providing gridded data used in this study.

\section{Conflicts of Interest}

The authors declare no conflicts of interest regarding the publication of this paper.

\section{References}

[1] IPCC (2018) Summary for Policymakers. In: Masson Delmotte, V., Zhai, P., Portner, H.O., Roberts, D.C., Skea, J., Shukla, P.R., Pirani, A., Mouffouma-Okia, W., Pean, C., Pidcock, R., Connors, S., Matthews, J.B.R., Chen, Y., Zhou, X., Gomis, M.I., Lonnoy, E., Maycock, T., Tignor, M. and Waterfield, T., Eds., Global Warming of $1.50{ }^{\circ} \mathrm{C}$. An IPCC Special Report on the Impacts of Global Warming of $1.50{ }^{\circ} \mathrm{C}$ above Pre-Industrial Levels and Related Global Greenhouse Gas Emission Pathways, in the Context of Strengthening the Global Response to the Threat of Climate Change, Sustainable Development, and Efforts to Eradicate Poverty, World Meteorological Organization, Geneva, $32 \mathrm{p}$.

[2] IPCC (2019) Summary for Policymakers. In: Shukla, P.R., Skea, J., Calvo Buendia, E., Masson Delmotte, V., Portner, H.O., Roberts, D.C., Zhai, P., Slade, R., Connors, S., van Diemen, R., Ferrart, M., Haughey, E., Luz, S., Neogi, S., Pathak, M., Petzold, J., Portugal Pereira, J., Vyas, P., Huntley, E., Kissick, K., Belkacemi, M. and Malley, J., Eds., Climate Change and Land: An IPCC Special Report on Climate Change, Desertification, Land Degradation, Sustainable Land Management, Food Security, 
and Greenhouse Gas Fluxes in Terrestrial Ecosystems, Cambridge University Press, Cambridge, p. 36. (In Press)

[3] IPCC (2019) Summary for Policymakers. In: Portner, H.O., Roberts, D.C., Masson Delmotte, V., Zhai, P., Tignor, M., Poloczanska, E., Mintenbeck, K., Alegria, A., Nicolai, M., Okem, A., Petzold, J., Rama, B. and Weyer, N.M., Eds., IPCC Special Report on the Ocean and Cryosphere in a Changing Climate, Cambridge University Press, Cambridge, p. 35. (In Press)

[4] Anande, D. and Luhunga, P. (2019) Assessment of Socio-Economic Impacts of the December 2011 Flood Event in Dar es Salaam, Tanzania. Atmospheric and Climate Sciences, 9, 421-437. https://doi.org/10.4236/acs.2019.93029

[5] Chang'a, L., Kijazi, A., Mafuru, K., Kondowe, A., Osima, S., Mtongori, H., Ng'ongolo, H., Juma, O. and Michael, E. (2020) Assessment of the Evolution and Socio-Economic Impacts of Extreme Rainfall Events in October 2019 over the East Africa. Atmospheric and Climate Sciences, 10, 319-338. https://doi.org/10.4236/acs.2020.103018

[6] Chang'a, L., Kijazi, A., Luhunga, P., Ng'ongolo, H. and Mtongori, H. (2017) Spatial and Temporal Analysis of Rainfall and Temperature Extreme Indices in Tanzania. Atmospheric and Climate Sciences, 7, 525-539. https://doi.org/10.4236/acs.2017.74038

[7] Chang'a, L.B., Pius, Z.Y. and James, N. (2010) Spatial and Temporal Analysis of Recent Climatological Data in Tanzania. Journal of Geography and Regional Planning, 3, 44-65.

[8] World Meteorological Organization (2020) WMO Statement on the State of Global Climate in 2019. WMO, Geneva.

[9] Nicholson, S.E. (2017) Climate and Climatic Variability of Rainfall over Eastern Africa. Reviews of Geophysics, 55, 590-635. https://doi.org/10.1002/2016RG000544

[10] Mafuru Biseke, K. and Tan, G. (2019) The Influence of ENSO on the Upper Warm Temperature Anomaly Formation Associated with the March-May Heavy Rainfall Events in Tanzania. International Journal of Climatology, 40, 2745-2763. https://doi.org/10.1002/joc.6364

[11] Allan, R., Reason, C., Lindesay, J. and Ansell, T. (2003) Protracted ENSO Episodes and Their Impacts in the Indian Ocean Region. Deep Sea Research Part II: Topical Studies in Oceanography, 50, 2331-2347. https://doi.org/10.1016/S0967-0645(03)00059-6

[12] Karumuri, A., Guan, Z.Y. and Yamagata, T. (2001) Impact of the Indian Ocean Dipole on the Relationship between the Indian Monsoon and ENSO. Journal of Geographical Research, 28, 4499-4502. https://doi.org/10.1029/2001GL013294

[13] Swadhil, B. and Toshio, Y. (2001) Subtropical SST Dipole in the Southern Indian Ocean. Journal of Geographical Research Letters, 28, 327-330.

https://doi.org/10.1029/2000GL011451

[14] Kijazi, A.L. and Reason, C.J.C. (2005) Relationship between Intra-Seasonal Rainfall Variability of Coastal Tanzania and ENSO. Theoretical and Applied Climatology, 82, 153-176. https://doi.org/10.1007/s00704-005-0129-0

[15] Kijazi, A.L. and Reason, C.J.C. (2009) Analysis of the 2006 Floods over Northern Tanzania. International Journal of Climatology, 29, 955-970. https://doi.org/10.1002/joc.1846

[16] Mapande, A.T. and Reason, C.J.C. (2005) Links between Rainfall Variability on Intra-Seasonal and Inter-Annual Scales over Western Tanzania and Regional Circulation and SST Patterns. Meteorology and Atmospheric Physics, 89, 215-234. 
https://doi.org/10.1007/s00703-005-0130-2

[17] Saji, N.H., Goswami, B.N., Vinayachandran, P.N. and Yamagata, T. (1999) A Dipole Mode in the Tropical Indian Ocean. Nature, 401, 360-363.

https://doi.org/10.1038/43854

[18] Saji, N.H. and Yamagata, T. (2003) Structure of SST and Surface Wind Variability during Indian Ocean Dipole Mode Events: COADS Observations. Journal of Climate, 16, 2735-2751.

https://doi.org/10.1175/1520-0442(2003)016<2735:SOSASW>2.0.CO;2

[19] Ogallo, L.A. (1989) The Spatial and Temporal Patterns of East African Seasonal Rainfall Derived from Principal Component Analysis. International Journal of Climatology, 9, 145-167. https://doi.org/10.1002/joc.3370090204

[20] Chris, F., Pete, P., Martin, L., Diego, P., Vewland, J., et al. (2015) The Climate Hazards Infrared Precipitation with Stations-A New Environmental Record for Monitoring Extremes. Scientific Data, 2, Article ID: 150066. https://doi.org/10.1038/sdata.2015.66

[21] Smith, T.M., Reynolds, R.W., Peterson, T.C. and Lawrimore, J. (2008) Improvements to NOAA's Historical Merged Land-Ocean Surface Temperature Analysis (1880-2006). Journal of Climate, 21, 2283-2296.

https://doi.org/10.1175/2007JCLI2100.1

[22] Roundy, P.E. (2015) On the Interpretation of EOF Analysis of ENSO, Atmospheric Kelvin Waves, and the MJO. Journal of Climate, 28, 1148-1165. https://doi.org/10.1175/JCLI-D-14-00398.1

[23] Mann, H.B. (1945) Non-Parametric Test against Trend. Econometrica, 13, 245-259. https://doi.org/10.2307/1907187

[24] Kendall, M.G. (1975) Rank Correlation Methods. 4th Edition, Charles Griffin, London.

[25] Mosmann, V., Castro, A., Fraile, R., Dessens, J. and Sanches, J. (2004) Detection of Statistically Significant Trends in the Summer Precipitation of Mainland Spain. Atmospheric Research, 70, 43-53. https://doi.org/10.1016/j.atmosres.2003.11.002

[26] Moraes, J.M., Pellegrino, H.Q. and Ballester, M.V. (1998) Trends in Hydrological Parameters of Southern Brazilian Water Shed and Its Relation to Human Induced Changes. Water Resources Management, 12, 295-311.

https://doi.org/10.1023/A:1008048212420

[27] Mafuru, K.B. and Guirong, T. (2018) Assessing Prone Areas to Heavy Rainfall and the Impaction of the Upper Warm Temperature Anomaly during March-May Rainfall Season in Tanzania. Advances in Meteorology, 2018, Article ID: 8353296. https://doi.org/10.1155/2018/8353296

[28] World Bank (2019) The Role of Poverty in Exposure, Vulnerability and Resilience to Floods in Dar es Salaam. Policy Research Working Paper 8976. 